\title{
Upaya Meningkatkan Hasil Belajar Materi Menceritakan Sejarah Indonesia Melalui Penerapan Metode Pembelajaran Word Square dan Scramble
}

\author{
Yonni Antoko \\ SDN Medokan Ayu II/615 Surabaya \\ Jl. Komp. YKP MA I L No.23, Kecamatan Rungkut, Kota Surabaya \\ yonniantoko@gmail.com
}

\begin{abstract}
This study aims to determine whether there is an increase in Learning Outcomes of Indonesian History Telling Materials through the application of Word Square and Scramble learning methods to 6th Grade students of SDN Medokan Ayu II/615 Surabaya, and to find out how much increase in Learning Outcomes of Indonesian History Telling Materials through the application of learning methods. Word Square and Scramble for Class 6 students at SDN Medokan Ayu II/615 Surabaya. Action research was carried out in two learning cycles by applying the Word Square and Scramble learning methods in Indonesian Language Subjects as the object of research. In the study, it was found that the authentic value and learning outcomes of students' storytelling history of Indonesia increased. This can be seen from the increase in students' learning outcomes of Telling Indonesian History from before this learning method was applied which only had an average of 53.8 to 71.3 in the first cycle and 77.7 in the second cycle. In addition, it was also found an increase in the percentage of classical completeness from cycle to cycle. Classical completeness in the first cycle was $59 \%$ with a moderately increasing category in the second cycle of $82 \%$ with a very good category. Based on the explanation of the results of the research and discussion, it can be concluded that there is an increase in Learning Outcomes of Indonesian History Telling Materials through the application of the Word Square and Scramble learning methods to the 6th grade students of SDN Medokan Ayu II/615 Surabaya.
\end{abstract}

Keywords: Learning Outcomes, Learning Methods, Word Square, Scramble

\begin{abstract}
Abstrak
Penelitian ini bertujuan untuk mengetahui ada tidaknya peningkatan Hasil Belajar Materi Menceritakan Sejarah Indonesia melalui penerapan metode pembelajaran Word Square dan Scramble pada siswa Kelas 6 SDN Medokan Ayu II/615 Surabaya, dan untuk mengetahui seberapa besar peningkatan Hasil Belajar Materi Menceritakan Sejarah Indonesia melalui penerapan metode pembelajaran Word Square dan Scramble pada siswa Kelas 6 SDN Medokan Ayu II/615 Surabaya. Penelitian tindakan dilaksanakan dalam dua siklus pembelajaran dengan menerapkan metode pembelajaran Word Square dan Scramble pada Mata Pelajaran Bahasa Indonesia sebagai obyek penelitian. Dalam penelitian ditemukan fakta bahwa nilai autentik dan hasil belajar materi Menceritakan Sejarah Indonesia pada siswa meningkat. Hal ini terlihat dari peningkatan hasil belajar materi Menceritakan Sejarah Indonesia siswa dari sebelum diterapkan metode pembelajaran ini yang hanya memiliki rata-rata 53,8 menjadi 71,3 pada siklus I dan 77,7 pada siklus II. Selain itu juga ditemukan kenaikan persentase ketuntasan klasikal dari siklus ke siklus. Ketuntasan klasikal pada siklus I sebesar 59\% dengan kategori cukup naik pada siklus II sebesar 82\% dengan kategori sangat baik. Berdasarkan paparan hasil penelitian dan pembahasan, dapat dirumuskan kesimpulan penelitian bahwa ada peningkatan Hasil Belajar Materi Menceritakan Sejarah Indonesia melalui penerapan metode pembelajaran Word Square dan Scramble pada siswa Kelas 6 SDN Medokan Ayu II/615 Surabaya.
\end{abstract}

Kata kunci: Hasil Belajar, Metode Pembelajaran, Word Square, Scramble

Copyright (c) 2021 Yonni Antoko

Corresponding author: Yonni Antoko

Email Address: yonniantoko@gmail.com (Jl. Komp. Ykp Ma I L No.23, Kecamatan Rungkut, Kota Surabaya)

Received 09 September 2021, Accepted 06 October 2021, Published 10 November 2021

\section{PENDAHULUAN}

Sekolah sebagai lembaga pendidikan sesungguhnya mempunyai fungsi ganda. Fungsi ganda 
tersebut adalah selain memberikan layanan kepada masyarakat, sekolah juga berfungsi sebagai agen pembaharu bagi masyarakat. Artinya sekolah selain berfungsi memberikan pendidikan dan pegajaran kepada warga masyarakat, juga berfungsi untuk mengakomodasi dan mengembangkan sumber daya masyarakat setempat, termasuk selalu berusaha untuk mensosiolisasikan sosiokultural masyarakat kepada siswa.

Setiap kurikulum yang telah berlaku di Indonesia dari periode sebelum tahun 1945 hingga kurukulum 2013, memiliki beberapa perbedaan sistem. Perbedaan sistem yang terjadi bisa merupakan kelebihan maupun kekurangan dari kurikulum itu sendiri. Kekurangan dan kelebihan tersebut dapat berasal dari landasan, komponen, evaluasi, prinsip, metode, maupun model pengembangan kurikulum. Untuk memperbaiki kekurangan yang ada, maka disusunlah kurikulum yang baru yang diharapkan akan sesuai dengan kebutuhan masyarakat dan tuntutan zaman. Oleh karena itu, kurikulum di Indonesia akan senantiasa berkembang maupun berubah sesuai yang disebutkan sebelumnya.

Indonesia adalah bangsa yang pluralis (Plural society), terdiri dari berbagai suku bangsa, agama dan kepercayaan yang dianutnya. Setiap suku atau daerah memiliki keaneka ragaman serta perbedaan kebudayaan berupa adat istiadat, tatakrama pergaulan, bahasa dan tulisan, legenda, sera nilai-nilai sosial, agama dan kepercayaan. Dengan berbagai keanekaragaman tersebut, tentunya tidak dapat diformulasi dan diakomodasi dan dirumuskan secara menyeluruh ke dalam kurikulum nasional secara sentralisasi. Oleh karena itu, mata pelajaran sebagai wujud pengembangan kurikulum yang berorientasi kedaerahan sangat tepat dan strategis untuk diterapkan di sekolah.

Bahasa Indonesia sebagai salah satu bidang studi yang memiliki tujuan membekali siswa untuk mengembangkan bahasa di samping aspek penalaran dan hafalan sehingga pengetahuan dan informasi yang diterima siswa sebatas produk bahasa dan sastra. Padahal dalam proses belajar mengajar keterlibatan siswa secara totalitas, artinya melibatkan pikiran, penglihatan, pendengaran dan psikomotor (keterampilan, salah satunya sambil menulis). Jadi dalam proses belajar mengajar, seorang guru harus mengajak siswa untuk mendengarkan, menyajikan media yang dapat dilihat, memberi kesempatan untuk menulis dan mengajukan pertanyaan atau tanggapan, sehingga terjadi dialog kreatif yang menunjukkan proses belajar mengajar yang interaktif.

Berdasarkan observasi awal yang dilakukan terkait rendahnya Hasil Belajar Materi Menceritakan Sejarah Indonesia yang dialami oleh siswa Kelas 6 SDN Medokan Ayu II/615, maka penulis sebagai Guru Kelas bertanggung jawab untuk menemukan solusi untuk meningkatkan Hasil Belajar Materi Menceritakan Sejarah Indonesia. Perspektif yang diambil adalah meningkatkan aktivitas siswa pada proses belajar mengajar. Hal ini berkaitan dengan pemilihan metode pembelajaran, oleh karenanya inovasi penerapan model dan metode pembelajaran harus dilakukan melalui bentuk penerapan metode pembelajaran Word Square dan Scramble.

Guru yang dalam hal ini penulis dituntut untuk mampu menyesuaikan, memilih dan memadukan berbagai jenis metode serta metode pembelajaran dalam menyampaikan materi. Hal ini bertujuan untuk mempermudah siswa dalam menerima materi yang disampaikan dan menghindari rasa 
jenuh siswa, sehingga diharapkan dengan menggunakan metode pembelajaran Word Square dan Scramble dalam pembelajaran mata pelajaran Bahasa Indonesia ini dapat meningkatkan hasil belajar Materi Menceritakan Sejarah Indonesia siswa Kelas 6 SDN Medokan Ayu II/615.

Penelitian ini bertujuan untuk mengetahui ada tidaknya peningkatan Hasil Belajar Materi Menceritakan Sejarah Indonesia melalui penerapan metode pembelajaran Word Square dan Scramble pada siswa Kelas 6 SDN Medokan Ayu II/615, dan untuk mengetahui seberapa besar peningkatan Hasil Belajar Materi Menceritakan Sejarah Indonesia melalui penerapan metode pembelajaran Word Square dan Scramble pada siswa Kelas 6 SDN Medokan Ayu II/615.

\section{Keterampilan Bercerita}

Bercerita merupakan kegiatan berbahasa yang bersifat produktif. Artinya, dalam bercerita seseorang melibatkan pikiran, kesiapan mental, keberanian, perkataan yang jelas sehingga dapat dipahami oleh orang lain. Menurut Burhan Nurgiyantoro (2001: 278), ada beberapa bentuk tugas kegiatan berbicara yang dapat dilatih untuk meningkatkan dan mengembangkan keterampilan bercerita pada siswa, yaitu (1) bercerita berdasarkan gambar, (2) wawancara, (3) bercakap-cakap, (4) berpidato, (5) berdiskusi.

Bercerita merupakan salah satu kebiasaan masyarakat sejak dahulu sampai sekarang. Hampir setiap siswa yang telah menikmati suatu cerita akan selalu siap untuk menceritakannya kembali, terutama jika cerita tersebut mengesankan bagi siswa. Menurut Burhan Nurgiyantoro (2001: 289), bercerita merupakan salah satu bentuk tugas kemampuan berbicara yang bertujuan untuk mengungkapkan kemampuan berbicara yang bersifat pragmatis. Ada dua unsur penting yang harus dikuasai siswa dalam bercerita yaitu linguistik dan unsur apa yang diceritakan. Ketepatan ucapan, tata bahasa, kosakata, kefasihan dan kelancaran, menggambarkan bahwa siswa memiliki kemampuan berbicara yang baik.

Tarigan (1981: 35) menyatakan bahwa bercerita merupakan salah satu keterampilan berbicara yang bertujuan untuk memberikan informasi kepada orang lain. Dikatakan demikian karena bercerita termasuk dalam situasi informatif yang ingin membuat pengertian-pengertian atau maknamakna menjadi jelas. Dengan bercerita, seseorang dapat menyampaikan berbagai macam cerita, ungkapan berbagai perasaan sesuai dengan apa yang dialami, dirasakan, dilihat, dibaca dan ungkapan kemauan dan keinginan membagikan pengalaman yang diperolehnya.

Keterampilan bercerita yang baik memerlukan pengetahuan, pengalaman serta kemampuan berpikir yang memadai. Selain itu dalam bercerita juga diperlukan penguasaan beberapa keterampilan, yaitu ketepatan tatabahasa sehingga hubungan antar kata dan kalimat menjadi jelas. Ketepatan kata dan kalimat sangat perlu dikuasai dalam bercerita, sebab dengan menggunakan kata dan kalimat yang tepat dalam bercerita akan memudahkan pendengar memahami isi cerita yang dikemukakan oleh pembicara. Isi cerita yang mudah dipahami akan menunjang dalam penyampaian maksud yang sama antara pembicara dan pendengar, sehingga tujuan penyampaian makna cerita juga dapat tercapai.

Selain itu dalam bercerita diperlukan kelancaran dalam menyampaikan kalimat per kalimat. 
Kelancaran dalam menyampaikan isi cerita akan menunjang pembicara dalam menyampaikan isi cerita secara runtut dan lancar sehingga penyimak/pendengar yang mendengarkan dapat antusias dan tertarik mendengarkan cerita.

Bercerita merupakan salah satu keterampilan berbahasa yang bersifat produktif yang berarti menghasilkan ide, gagasan, dan buah pikiran (Yeti Mulyati, 2009: 64). Ide, gagasan, dan pikiran seorang pembicara memiliki hikmah atau dapat dimanfaaatkan oleh penyimak/pendengar, misalnya seorang guru berbicara dalam mentransfer ilmu pengetahuan kepada siswa, sehingga ilmu tersebut dapat dipraktikkan dan dimanfaatkan oleh siswa dalam kehidupan sehari-hari. Tarigan (1981: 17) mengungkapkan tiga tujuan umum dari kegiatan bercerita yaitu sebagai berikut:

1. Memberitahukan dan melaporkan (to inform),

2. Menjamu dan menghibur (to entertain),

3. Membujuk, mengajak, mendesak, dan meyakinkan (to persuade).

Sedangkan, Bachtiar S. Bachri (2005: 11), mengatakan bahwa manfaat bercerita adalah dapat memperluas wawasan dan cara berfikir anak, sebab dalam bercerita anak mendapat tambahan pengalaman yang bisa jadi merupakan hal baru baginya.

\section{Pembelajaran dan Penillaian Materi Bercerita}

Pembelajaran adalah proses mempelajari. Mudini dan Salamat Purba (2009: 18) mengungkapkan bahwa pembelajaran ialah pengalaman yang dialami murid dalam proses menguasai kompetensi dasar. Di dalam Kurikulum 2013 dinyatakan bahwa belajar bahasa adalah belajar berkomunikasi. Pernyataan tersebut berarti bahwa siapa pun yang mempelajari suatu bahasa pada hakikatnya sedang belajar berkomunikasi. Dalam pembelajaran berceritapun seseorang berarti belajar untuk berkomunikasi.

Pembelajaran bercerita dapat berlangsung jika setidak-tidaknya ada dua orang yang berinteraksi, atau seorang yang bercerita dan pendengar yang mendengarkan cerita tersebut. Adapun karakteristik yang harus ada dalam kegiatan pembelajaran bercerita menurut Mudini dan Salamat Purba (2009: 19-20) yakni sebagai berikut:

1. Harus ada pendengar,

2. Penguasaan lafal, struktur, dan kosa kata,

3. Ada tema/topik yang diceritakan,

4. Ada informasi yang ingin disampaikan atau sebaliknya ditanyakan,

5. Memperhatikan situasi dan konteks.

Setiap kegiatan pembelajaran perlu diadakan penilaian termasuk dalam pembelajaran kegiatan berbahasa dalam hal ini khususnya adalah keterampilan bercerita. Cara yang digunakan untuk mengetahui sejauh mana siswa mampu terampil dalam bercerita adalah dengan melakukan observasi atau pengamatan keterampilan bercerita. Observasi merupakan suatu teknik dalam melakukan evaluasi yang di dalamnya terdapat serangkaian pengamatan yang harus dilakukan oleh pengamat atau guru. Burhan Nurgiyantoro (2010: 57) membedakan observasi menjadi dua macam yaitu observasi 
berstruktur dan tak berstruktur. Dalam observasi berstruktur, kegiatan pengamat telah diatur, dibatasi dengan kerangka kerja tertentu yang telah disusun secara sistematis. Sedangkan, observasi tak berstruktur tidak membatasi pengamat dengan kerangka kerja tertentu.

Observasi yang digunakan dalam penelitian ini menggunakan observasi terstruktur dengan kerangka kerja yang telah disusun berdasarkan aspek-aspek dalam bercerita. Adapun aspek-aspek bercerita yang dinilai menurut Burhan Nurgiyantoro (2010: 410) meliputi (1) ketepatan isi cerita, (2) ketepatan penunjukkan detil cerita, (3) ketepatan logika cerita, (4) ketepatan makna seluruh cerita, (5) ketepatan kata, (6) ketepatan kalimat, dan (7) kelancaran.

Bercerita merupakan kegiatan untuk menyampaikan pesan atau informasi kepada orang lain secara lisan. Dalam menyampaikan pesan atau informasi seorang pembicara harus memperhatikan faktor-faktor yang dapat menunjang keefektifan bercerita. Adapun faktor yang harus diperhatikan adalah faktor kebahasaan dan nonkebahasaan. Arsjad dan Mukti (1993: 17-22) mengemukakan faktorfaktor kebahasaan dan nonkebahasaan yang dapat menunjang kekefektifan bercerita sebagai berikut: faktor kebahasaan meliputi : (a) ketepatan ucapan, (b) penekanana tekanan nada, sendi dan durasi, (c) pilihan kata, (d) ketepatan penggunaan kalimat, (e) ketepatan sasaran pembicaraan; faktor nonkebahasaan meliputi: (1) sikap yang wajar, tenang, dan tidak kaku, (2) pandangan harus diarahkan pada lawan bicara, (3) kesediaan menghargai pendapat orang lain, (4) gerak-gerik dan mimik yang tepat, (5) kenyaringan suara, (6) relevansi/penalaran, (7) penguasaan topik.

Sedangkan, faktor yang menghambat dalam keefektifan keterampilan bercerita yaitu: (a) faktor fisik, merupakan faktor yang ada dalam partisipan sendiri dan faktor yang berasal dari luar partisipan, (b) faktor media, terdiri dari faktor linguistik dan faktor nonlinguistik (misalnya tekanan, lagu, irama, ucapan dan isyarat gerak tubuh), (c) faktor psikologis, merupakan kondisi kejiwaan partisipan dalam keadaan marah, menangis, dan sakit.

Dalam kegiatan bercerita, perlu adanya suatu rencana untuk menentukan pokok-pokok cerita yang akan dikomunikasikan. Menurut Tarigan (1981: 32) dalam merencanakan suatu pembicaraan atau bercerita harus mengikuti langkah-langkah: (1) menentukan topik cerita yang menarik, (2) menyusun kerangka cerita dengan mengumpulkan bahan-bahan, (3) mengembangkan kerangka cerita, dan (4) menyusun teks cerita.

\section{Metode Pembelajaran Word Square}

Metode pembelajaran Word Square merupakan pengembangan dari metode ceramah yang diperkaya. Hal ini dapat diidentifikasi melalui pengelompokkan metode ceramah yang diperkaya yang berorientasi kepada keaktifan siswa dalam pembelajaran sebagaimana disebutkan oleh Mujiman (2007) Metode pembelajaran Word Square merupakan metode pembelajaran yang memadukan kemampuan menJawab pertanyaan dengan kejelian dalam mencocokan pada kotak-kotak Kalimat. Mirip seperti mengisi Teka-Teki Silang tetapi bedanya jawabannya sudah ada namun disamarkan dengan menambahkan kotak tambahan dengan sembarang huruf/angka penyamar atau pengecoh. Metode pembelajaran ini sesuai untuk semua mata pelajaran. Tinggal bagaimana Guru dapat memprogram 
sejumlah pertanyaan terpilih yang dapat merangsang siswa untuk berpikir efektif. Tujuan huruf/angka pengecoh bukan untuk mempersulit siswa namun untuk melatih sikap teliti dan kritis.

Word Square merupakan salah satu dari sekian banyak metode pembelajaran yang dapat dipergunakan guru dalam mencapai tujuan pembelajaran. Metode ini merupakan kegiatan belajar mengajar dengan cara guru membagikan lembar kegiatan atau lembar kerja sebagai alat untuk mengukur tingkat pemahaman siswa terhadap materi pelajaran yang telah diajarkan. Instrumen utama metode ini adalah lembar kegiatan atau kerja berupa pertanyaan atau kalimat yang perlu dicari jawabannya pada susunan huruf acak pada kolom yang telah disediakan.

Langkah-langkah Metode pembelajaran Word Square adalah sebagai berikut:

1. Guru menyampaikan materi sesuai kompetensi yang ingin dicapai.

2. Guru membagikan lembaran kegiatan sesuai contoh.

3. Siswa menjawab soal kemudian mengarsir huruf dalam kotak sesuai Kalimat secara vertikal, horizontal maupun diagonal.

4. Guru memberikan poin setiap Kalimat dalam kotak

Beberapa kelebihan dari metode pembelajaran Word Square yaitu:

1. Kegiatan tersebut mendorong pemahaman siswa terhadap materi pelajaran.

2. Melatih untuk berdisiplin.

3. Dapat melatih sikap teliti dan kritis.

4. Merangsang siswa untuk berpikir efektif.

Metode pembelajaran ini mampu sebagai pendorong dan penguat siswa terhadap materi yang disampaikan. Melatih ketelitian dan ketepatan dalam menJawab dan mencari Kalimat dalam lembar kerja. Dan tentu saja yang ditekankan disini adalah dalam berpikir efektif, Kalimat mana yang paling tepat. Sedangkan beberapa kekurangan dari metode pembelajaran Word Square yaitu:

a. Mematikan kreatifitas siswa.

b. Siswa tinggal menerima bahan mentah.

c. Siswa tidak dapat mengembangkan materi yang ada dengan kemampuan yang dimilikinya.

Dalam metode pembelajaran ini siswa tidak dapat mengembangkan kreativitas masing-masing, dan lebih banyak berpusat pada guru. Karena siswa hanya menerima apa yang disampaikan oleh guru, dan Kalimat dari lembar kerja pun tidak bersifat analisis, sehingga siswa tidak dapat menggali lebih dalam materi yang ada dengan metode pembelajaran Word Square ini.

Berdasarkan penjelasan tentang metode pembelajaran Word Square maka dapat disimpulkan bahwa metode pembelajaran Word Square adalah suatu pengembangan dari metode ceramah namun untuk mengetahui pemahaman siswa tentang materi yang telah disampaikan maka diberikan lembar kerja yang didalamnya berisi soal dan Kalimat yang terdapat dalam kotak kata. Membutuhkan suatu kejelian dan ketelitian dalam mencari pilihan Kalimat yang ada dengan tepat. Namun sebagaimanan metode pembelajaran yang lainnya, metode pembelajaran Word Square mempunyai kekurangan dan kelebihan. Kekurangan dari metode pembelajaran ini yaitu siswa hanya menerima bahan mentah dari 
guru dan tidak dapat mengembangkan kreativitasnya, karena siswa hanya dituntut untuk mencari Kalimat bukan untuk mengembangkan pikiran siswa masing-masing. Sedangkan kelebihannya yaitu meningkatkan ketelitian, kritis dan berfikir efektif siswa. Karena siswa dituntut untuk mencari Kalimat yang paling tepat dan harus jeli dalam mencari Kalimat yangada dalam lembar kerja.

\section{Metode Pembelajaran Scramble}

Metode pembelajaran Scramble tampak seperti Metode pembelajaran Word Square, bedanya Kalimat soal tidak dituliskan di dalam kotak-kotak Kalimat, tetapi sudah dituliskan namun dengan susunan yang acak, nah siswa nanti bertugas mengkoreksi (membolak-balik huruf) Kalimat tersebut sehingga menjadi Kalimat yang tepat/ benar. Metode pembelajaran Scramble tampak seperti metode pembelajaran Word Square, bedanya Kalimat soal tidak dituliskan di dalam kotak-kotak Kalimat, tetapi sudah dituliskan, namun dengan susunan yang acak, jadi siswa bertugas mengoreksi (membolak-balik huruf) Kalimat tersebut sehingga menjadi Kalimat yang tepat / benar.

Kelebihan metode ini adalah:

1. Memudahkan mencari Kalimat

2. Mendorong siswa untuk belajar mengerjakan soal tersebut

3. Semua siswa terlibat

4. Kegiatan tersw dapat mendorong pemahaman siswa terhadap materi pelajaran

5. Melatih untuk disiplin

Adapun Kelemahan metode ini adalah:

1. Siswa kurang berfikir kritis

2. Bisa saja mencontek Kalimat teman lainnya

3. Mematikan kreatifitas siswa

4. Siswa tinggal menerima bahan mentah

Sedangkan langkah-langkah metode ini adalah:

1. Guru menyajikan materi sesuai topic, misalnya guru menyajikan materi pelajaran tentang cerita wayang.

2. Setelah selesai menjelaskan tentang cerita wayang, guru membagikan lembar kerja dengan Kalimat yang diacak susunannya.

3. Media yang digunakan dalam metode pembelajaran Scramble:

4. Buat pertanyaan yang sesuai dengan tujuan pembelajaran

5. Buat Kalimat yang diacak hurufnya

\section{METODE}

\section{Setting Penelitian}

Penelitian ini berlangsung dalam dua siklus, dan masing-masing siklus terdiri dari empat momen (fase) dalam spiral perencanaan, tindakan (action), observasi, dan refleksi yang oleh Kemmis dan McTaggart (1988) diilustrasikan dalam model PTK spiral. Dalam praktik, Kemmis dan McTaggart 
menyatakan model ini tidak boleh digunakan secara kaku, karena dalam kenyataan proses rencana tindakan - observasi - refleksi tersebut tidak berlangsung serapi model tersebut. Fase-fase itu biasanya berlangsung tumpang tindih.

Dengan demikian penulis dapat memperbaiki strategi tersebut secara optimal sehingga pengimplementasian strategi revisi ini nantinya dapat mencapai semua target keberhasilan. Strategi yang sudah diperbaiki (revised strategy) inilah yang menjadi fase perencanaan (plan) pada siklus berikutnya, yang nantinya diimplemetasikan, diobservasi, dan direfleksi kembali. Siklus tersebut dapat diulang beberapa kali hingga seluruh kriteria keberhasilan tercapai. Jumlah siklus tidak dapat diprediksi pada awal penelitian. Jika setelah siklus pertama semua kriteria keberhasilan dapat dicapai maka penelitian dapat dihentikan. Namun selama kriteria-kriteria keberhasilan itu belum tercapai, revisi terhadap strategi perlu dilakukan dan siklus berikutnya dilaksanakan.

\section{Subyek Penelitian}

Penelitian ini dilaksanakan oleh penulis di SDN Medokan Ayu II/615 dengan alamat Jl. Komplek YKP MA. I Blok L No. 23-25 Kecamatan Rungkut Kota Surabaya. Pelaksanaan penelitian dijadwalkan oleh penulis dengan rincian jadwal sebagai berikut:

Tabel 1. Waktu Pelaksanaan Tindakan

\begin{tabular}{|l|l|c|c|c|}
\hline No & \multicolumn{1}{|c|}{ Jenis Kegiatan } & Januari & Pebruari & Maret \\
\hline 1 & Konsultasi dengan Kepala Sekolah. & M1 & & \\
\hline 2 & Mengajukan proposal penelitian. & M1 & & \\
\hline 3 & Mengajukan RPP & M2 & & \\
\hline 4 & Revisi RPP. & M3 & & \\
\hline 5 & Evaluasi kualitas RPP tahap akhir. & M4 & & \\
\hline 6 & Konsultasi dengan Observer. & M4 & M1-4 & \\
\hline 7 & Pelaksanaan siklus I. & & M1-4 & \\
\hline 8 & Pelaksanaan siklus II. & & M1-4 & \\
\hline 9 & Menyusun laporan tindakan. & & & M1-3 \\
\hline
\end{tabular}

Kelas yang dijadikan obyek perbaikan dan penelitian adalah Kelas 6 dengan jumlah siswa sebanyak 39 siswa.

\section{Teknik Pengumpulan Data}

Pengumpulan data PTK biasanya dilakukan dengan menggunakan (1) teknik dokumentasi, berupa data kelas, siswa dan perangkat pembelajaran guru, (2) teknik observasi, yang digunakan untuk mengukur atau menilai hasil dan proses belajar misalnya tingkah laku siswa pada proses belajar mengajar, serta (3) teknik tes yang digunakan secara tidak langsung. Dalam artian nilai tes dikonversikan sebagai bahan kajian kualitatif berdasarkan indikator yang dinilai.

\section{Validasi Data}

Validasi adalah suatu tindakan yang membuktikan bahwa suatu proses dapat memberikan hasil 
yang konsisten sesuai dengan spesifikasi yang telah ditetapkan dan terdokumentasi dengan baik. Validasi dilakukan bila ada perubahan yang mempengaruhi produk secara langsung (major modification), produk baru atau produk lama dengan metode baru, exiting dan legacy product.

Konsep validitas dalam aplikasinya untuk penelitian tindakan mengacu kepada kredibilitas dan derajat keterpecayaan dari hasil penelitian. Salah satu langkah dalam prosedur untuk mendapatkan derajat kepercayaan ialah melalui validasi, yang dalam penelitian kualitatif disukai dengan istilah verifikasi. Menurut Borg dan Gall (2003) terdapat lima tahap kriteria validitas, yaitu: validitas hasil, proses, demokratis, katalis, dan dialog.

Berdasarkan tahapan kriteria validitas, maka dalam penelitian ini validitas data menggunakan teknik Triangulasi Data. Triangulasi data yaitu mengecek keabsahan (validasi) data dengan mengkonfirmasikan data yang sama dari sumber yang berbeda untuk memastikan keabsahan (derajat kepercayaan).

\section{Teknik Analisa Data}

Pengumpulan data yang ada, selanjutnya dianalisis. Untuk menganalisis data tersebut, penulis memerlukan analisis data yang sesuai agar data yang diperoleh dapat dipertanggungJawabkan, maka dalam penelitian ini penulis menggunakan analisis data kualitatif dan analisis data kuantitatif.

Analisis data kualitatif pada penelitian ini diperoleh dari hasil observasi yang dilakukan oleh penulis yang memuat gambaran tingkat pengetahuan siswa terhadap suatu mata pelajaran, aktivitas dan antusiasme siswa saat mengikuti pelajaran setiap siklus.

Sedangkan analisis data kuantitatif diperoleh dari hasil tes siswa yang bertujuan untuk mengetahui pengetahuan siswa tentang materi pelajaran dari setiap siklus, di mana siswa secara individu telah belajar tuntas atau berhasil apabila sekurang-kurangnya mendapat nilai 2,6 (nilai konversi dari nilai 65 dengan perbandingan nilai terbesar 4:100) berdasarkan kartu yang dipegangnya melalui metode pembelajaran Word Square dan Scramble.

Standar penentuan ketuntasan belajar siswa menurut Sudjana (2006:109) sebagai berikut:

$$
\mathrm{P}=\frac{\sum \mathrm{fx}}{\mathrm{N}} 100 \%
$$

Keterangan:

P : $\quad$ Persentase ketuntasan secara individu.

$\sum \mathrm{f} \quad$ : Jumlah nilai yang diperoleh siswa.

$\mathrm{N} \quad$ : $\quad$ Nilai maksimal.

Sedangkan untuk mencari persentase ketuntasan secara klasikal menggunakan rumus:

$$
\mathrm{P}=\frac{\sum \mathrm{nx}}{\mathrm{N}} 100 \%
$$

Keterangan:

P : : Persentase ketuntasan belajar secara klasikal.

$\sum \mathrm{n} \quad$ : $\quad$ Jumlah siswa yang mendapat nilai $\geq 70$.

$\mathrm{N} \quad$ : Jumlah siswa seluruhnya. 
Data pengamatan dianalisis dengan menghitung rata-rata pada setiap siklus yang dilaksanakan, selanjutnya nilai rata-rata tersebut diklasifikasikan dengan kriteria sebagai berikut:

$\begin{array}{ll}76-100 & \text { : Sangat baik. } \\ 66-75 & \text { : Baik. } \\ 46-65 & \text { : Cukup. } \\ 0-45 & \text { : Kurang. }\end{array}$

\section{Indikator Kinerja}

Indikator kinerja disusun berdasarkan aktivitas siswa selama kegiatan belajar mengajar yang mengindikasikan munculnya keingintahuan mereka sehingga meningkatkan Hasil Belajar Materi Menceritakan Sejarah Indonesia sebagaimana terinci dalam tabel berikut:

Tabel 2. Indikator Kinerja

\begin{tabular}{|c|l|}
\hline No & $\begin{array}{c}\text { Indikator aktivitas siswa dalam metode } \\
\text { pembelajaran Word Square dan Scramble }\end{array}$ \\
\hline 1 & Mendorong atau menstimulasi \\
\hline 2 & Meyakinkan \\
\hline 3 & Menggerakkan \\
\hline 4 & Menginformasikan \\
\hline 5 & Menghibur \\
\hline
\end{tabular}

\section{HASIL DAN DISKUSI}

\section{Deskripsi Siklus I}

Materi pembelajaran pada siklus ini adalah Menyampaikan Cerita, tentang Sejarah Indonesia. Penilaian dilakukan dengan menggunakan teknik tes tertulis dengan butir soal atau tugas sebagaimana termaktub dalam buku siswa Tematik Kelas 6. Kegiatan pembelajaran yang dilakukan ini sesuai dengan langkah-langkah metode pembelajaran Word Square dan Scramble sebagai berikut:

1. Guru menyampaikan materi sesuai kompetensi yang ingin dicapai.

2. Guru membagikan lembaran kegiatan sesuai contoh.

3. Siswa menJawab soal kemudian mengarsir huruf dalam kotak sesuai Kalimat secara vertikal, horizontal maupun diagonal.

4. Sebagian lainnya menJawab pertanyaan yang Kalimatnya diacak penyusunannya.

5. Siswa diminta menjelaskan maksud Kalimat dengan bercerita.

6. Berikan poin setiap Kalimat dalam kotak.

7. Buat Kalimat yang diacak hurufnya

Penilaian observer tentang Aktivitas Guru pada Siklus I termasuk dalam kategori baik. Hal ini terlihat pada tahap pembelajaran kegiatan awal. Hal ini dipengaruhi oleh kemampuan guru dalam memotivasi siswa. Pada tahap kegiatan inti guru masih belum bisa melakukan improvisasi dan belum mengerti tentang langkah-langkah penyelesaian dalam pemecahan. Maka dari tinjauan ini, observer 
menyimpulkan bahwa pada tahap kegiatan Siklus I, tampaknya guru masih perlu bimbingan dalam hal mengimprovisasi langkah demi langkah dari metode yang digunakan.

Berdasarkan hasil observasi ditemukan fakta bahwa pada siklus I rata-rata nilai Hasil Belajar Materi Menceritakan Sejarah Indonesia siswa adalah 71,3 dan rata-rata kemampuan siswa dalam melaksanakan metode pembelajaran Word Square dan Scramble adalah 13,8 atau 69\%. Hal ini bila diinterpretasikan ke dalam tabel interpretasi dengan rata-rata 71,3 maka termasuk ke dalam kategori baik. Adapun ketuntasan klasikal pada siklus I sebesar 59\% dengan kategori cukup.

Selain bagi siswa, metode pembelajaran Word Square dan Scramble ini merupakan hal yang baru bagi penulis sehingga sempat agak bingung bagaimana cara menjelaskan aturan pelaksanaannya pada siswa. Di samping itu, penulis sempat meragukan apakah dengan model dan metode pembelajaran ini Hasil Belajar Materi Menceritakan Sejarah Indonesia siswa berubah.

\section{Deskripsi Siklus II}

Melihat pengalaman pembelajaran siklus I, guru mencoba beberapa perubahan dalam mengajar. Materi pembelajaran pada siklus ini adalah Menyampaikan Cerita, tentang Sejarah Indonesia. Penilaian dilakukan dengan menggunakan teknik tes tertulis dengan butir soal atau tugas sebagaimana tertuang dalam buku siswa Tematik Kelas 6. Kegiatan pembelajaran yang dilakukan ini sesuai dengan langkahlangkah metode pembelajaran Word Square dan Scramble sebagai berikut:

1. Guru menyampaikan materi sesuai kompetensi yang ingin dicapai.

2. Guru membagikan lembaran kegiatan sesuai contoh.

3. Siswa menJawab soal kemudian mengarsir huruf dalam kotak sesuai Kalimat secara vertikal, horizontal maupun diagonal.

4. Sebagian lainnya menJawab pertanyaan yang Kalimatnya diacak penyusunannya.

5. Siswa diminta menjelaskan maksud Kalimat dengan bercerita.

6. Berikan poin setiap Kalimat dalam kotak.

7. Buat Kalimat yang diacak hurufnya

Penilaian observer tentang Aktivitas Guru pada Siklus II termasuk dalam kategori sangat baik. Hal ini terlihat pada tahap pembelajaran kegiatan awal. Hal ini dipengaruhi oleh kepandaian guru dalam memotivasi siswa. Pada tahap kegiatan inti guru telah berhasil melakukan improvisasi pada langkahlangkah penyelesaian. Maka dari tinjauan ini, observer menyimpulkan bahwa pada tahap kegiatan Siklus II secara global berjalan dengan lancar.

Berdasarkan hasil observasi ditemukan fakta bahwa bahwa pada siklus II rata-rata nilai Hasil Belajar Materi Menceritakan Sejarah Indonesia siswa adalah 77,7 dan rata-rata kemampuan siswa dalam melaksanakan metode pembelajaran Word Square dan Scramble adalah 15,2 atau 76\%. Hal ini bila diinterpretasikan ke dalam tabel interpretasi dengan rata-rata 77,7 maka termasuk ke dalam kategori baik. Adapun ketuntasan klasikal pada siklus II sebesar 82\% dengan kategori sangat baik. 


\section{Diskusi}

Penerapan metode pembelajaran Word Square dan Scramble memiliki efektifitas untuk meningkatkan nilai autentik dan Hasil Belajar Materi Menceritakan Sejarah Indonesia siswa. Hal ini terlihat dari tanjakan persentase Hasil Belajar Materi Menceritakan Sejarah Indonesia siswa dari sebelum diterapkan metode pembelajaran ini yang hanya memiliki rata-rata 53,8 menjadi 71,3 pada siklus I dan 77,7 pada siklus II.

Peningkatan kemampuan siswa dalam melaksanakan metode pembelajaran Word Square dan Scramble sebesar $24 \%$ dari dua siklus ini jika ditelusuri lebih dalam adalah karena adanya faktor motivasi dari dalam diri siswa itu sendiri, apakah mereka mau menunjukkan seluruh aktivitas belajar yang menjadi indikator penelitian sepenuh hati mereka atau tidak. Model dan metode pembelajaran yang diterapkan hanyalah faktor stimulus untuk memunculkan pembiasaan pada diri siswa.

Anggapan penulis ini tentu saja masih perlu dibuktikan dengan penelitian tindakan kelas lanjutan dari penelitian ini tiga atau empat bulan ke depan untuk menilai apakah pembiasaan dengan penggunaan model dan metode pembelajaran tertentu memiliki signifikansi yang besar terhadap peningkatan Hasil Belajar Materi Menceritakan Sejarah Indonesia siswa.

\section{KESIMPULAN}

Berdasarkan paparan hasil penelitian dan pembahasan, dapat dirumuskan kesimpulan yaitu: ada peningkatan Hasil Belajar Materi Menceritakan Sejarah Indonesia melalui penerapan metode pembelajaran Word Square dan Scramble pada siswa Kelas 6 SDN Medokan Ayu II/615 Surabaya. Peningkatan Hasil Belajar Materi Menceritakan Sejarah Indonesia melalui penerapan metode pembelajaran Word Square dan Scramble pada siswa Kelas 6 SDN Medokan Ayu II/615 Surabaya ratarata sebesar 24\%. Upaya peningkatan Hasil Belajar Materi Menceritakan Sejarah Indonesia melalui penerapan metode pembelajaran Word Square dan Scramble dapat dijadikan acuan untuk mengadakan penelitian selanjutnya dengan sudut permasalahan berbeda atau solusi berbeda dengan permasalahan serupa. Selain itu juga dapat diimplementasikan sebagai bahan kajian bagi guru yang memiliki masalah dengan perilaku kurang terpuji siswa, khususnya siswa Kelas 6 SD agar dapat segera tertangani oleh karena adanya unsur terapi dan pembiasaan dalam model dan metode pembelajaran ini. Oleh kerenanya, penulis memberikan beberapa saran agar guru senantiasa memposisikan diri sebagai fasilitator bagi siswa dengan menciptakan suasana proses belajar mengajar yang tidak menjenuhkan, Guru harus kreatif dengan menerapkan berbagai model dan metode pembelajaran yang PAKEMIP. Guru seyogyanya sering memberi peluang kepada siswanya untuk berkomunikasi antarteman, guru dan masyarakat sekolah, tentang materi ajar

\section{UCAPAN TERIMA KASIH}

Terimakasih kami ucapkan kepada Kepala Sekolah dan Guru-Guru di SDN Medokan Ayu II/615 Surabaya yang telah memberikan kesempatan kepada peneliti dalam melaksanakan 
penelitian. Selain itu juga kepada siswa yang telah ikut berpartisipasi dalam melaksanakan penelitian ini.

\section{REFERENSI}

Arsjad, Maidar G \& Mukti U.S. (1993). Pembinaan Kemampuan Berbicara Bahasa Indonesia. Jakarta: Erlangga

Bachir, Bachtiar S. 2005. Pengembangan Kegiatan Bercerita di Taman KanakKanak dan Teknik dan Prosedurnya. Jakarta: Depdiknas.

Burhan Nurgiyantoro. 2001. Penilaian dalan Pengajaran Bahasa dan Sastra. Yogyakarta: BPFE Kemmis, S. \& Mc. Taggart, R. 1988. The Action Research Planner. Victoria: Deakin University Press Mudini dan Salamat Purba. 2009. "Pembelajaran Bercerita”. Jakarta: Modul Suplemen KKG Bermutu Mujiman. 2007. Model Pembelajaran Word Square. Jakarta: Raja Grafindo Persada

Mulyati, Yeti. 2009. Pendidikan Bahasa dan Sastra Indonesia di Kelas Tinggi. Jakarta: Universitas Terbuka

Tarigan, Henry Guntur. 1981. Berbicara Sebagai Suatu Keterampilan Berbahasa. Bandung: Angkasa Sudjana, Nana. (2006). Penilaian Hasil Proses Belajar Mengajar. Bandung: PT. Ramaja Rosdakarya 